\title{
数種の沈水植物細胞における 硝酸銀還元反応の検討*
}

\author{
吉田吕男** \\ Yoshio YoshidA**: Some Informations on the Silver Nitrate \\ Reduction in the Cells of Several Submerged Plants*
}

昭和 32 年 12 月 6 日受付

種々の生体組織に著しい硝酸銀還元能の女る寻 は古くから注目せられ, Szent-Györgyi (19281))以 来種々の研究結果からその還元要因が Ascorbic acidであることが決定せら独，更に Giroud et Leblond (1937)2) 等はこの反応から逆にアスコル ビン酸の組織化学的検出法を確立した。

植物細胞では特に生きている葉緑体において硝 酸銀を還元して黒くなる反応の強い事が知られ所 謂 “Molisch” 反応として多くの研究者により追 求されて来た。しかしな就より慎重な検討の望ま 狄ている点も少くはない。

ここでは Elodea その他の沈水植物の葉の細胞 に打けるこの反応を検討し, 又ペーパークロマト グラフィーによりその還元性物筫の検出を試みた 結果, 若干の知見を得たので報告する。

\section{材 料 と 方 法}

Elodea densa Casp., E. canadensis Michx., Hydrilla verticillata Casp., Ceratophyllum demersum L., Potomogeton crispus L.の 5 種の沈水植物の 新生葉を被娭材料として次の試薬及び処理につい て夫々の反応程度を観察した。酢酸々性, アンモ ニア性, 中性の $10 \%$ 硝酸銀液を試楽とし次の諸種 の処理を行った。(1) Giroud-Leblond 法: 酢酸々 性 $10 \%$ 硝酸銀液 $(\mathrm{pH} \div 3)$ に 30 分浸漬, D.W. で洗涤，チ才硫酸ソーダ $3.5 \%$ 溶液に 1 時間浸 漬, D.W. で洗涤, Glycerin で検鏡，i．これら の手順を暗黒中にて行ら。 ii. 普通室内散光中に て行万。(2) 酢酸々性, アンモニア性, 中性各硝

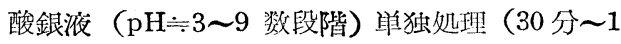
時閆浸漬)，ｉ．暗埋中にて行万。ii. 普通散光中に
て行う。(3) 試楽を大ライド上の被梌材料に滴下 しカバーをかけ直もに火焰を通して加熱す。 ペーパークロマトグラフィー：一次元上杽法, 東洋ろ紙 No. $50,2 \times 40 \mathrm{~cm}$ を用い, 展開剤はnブタノール 4 , 氷酢酸 1 , 水 5 , を分液ろと中に てよく混和し 2 3 日間放盅後上澄液を使用寸る。 被候液の調整は新鮮草体 $1.5 \mathrm{~g}$ に $5 \%$ ×夕燐酸 $1 \mathrm{cc}$ を加之乳鉢性て磨确，違心分離し上澄液を用いる。 ろ紙の下端から $7 \mathrm{~cm}$ を出発線とし, その中央点 に $0.02 \mathrm{cc}$ の検液を滴下し, 乾燥後スタンドに装 罨し下端 $1 \mathrm{~cm}$ 迄浸るように展開液を注入, 酵素 作用を抑制するため器底に少量の KCN の結晶を 投入し出発線より $30 \mathrm{~cm}$ の高さ迄展開上昇世し わ, 乾燥後試薬を吹きつけ発色せしめる。顕出 㓮としては上記各硝酸銀液の他 2-6-dichlorphenolindophenol $400 \mathrm{mg} / 150 \%$ ethanol 溶液 ( スコルビン酸の検出), Benzidin $0.5 \mathrm{~g}$, 䣷酸 $5 \mathrm{cc}$, 純アルコール $20 \mathrm{cc}$ の混液（100〜105 に 5 〜 15 分間扣熱処理, 遻元煻の検出), その他を使用 した。

\section{実 験 結 果}

Giroud-Leblond 法：暗処理では液胞，細胞質 が一様に淡く暗灰巴を旺し，葉緑体は僅かに暗䶂 色を带びる。明処理です殆んど同じ反志を示し， 暗と明とで特に差は認めら孔ない。

酷酸酸性試薬 $(\mathrm{pH} \fallingdotseq 3)$ : 液胞, 細胞質は一様に 喑灰色を呈し，葉緑体は弱く黒ずんでくる。

アンモニア性試楽 $(\mathrm{pH} \div 9)$ : 綿毛状暗在他沈殿 が液胞を充たす。しかし葉緑体の着色は殆んぞ負 に近い。

\footnotetext{
* 文部省助成金による。No.407041，昭和 30 年度，要旨は第 22 回植物学会大会（苯京）に報告。 ** 新潟大学理学部生物学教室 Department of Biology. Faculty of Science, Niigata University, Niigata, Japan.
} 
中性試薬 $(\mathrm{pH} \fallingdotseq 6)$ : 液胞は幾分暗灭色を带びメ 綿毛状沈殿も若干生ずる。葉緑体は多少黒化す。

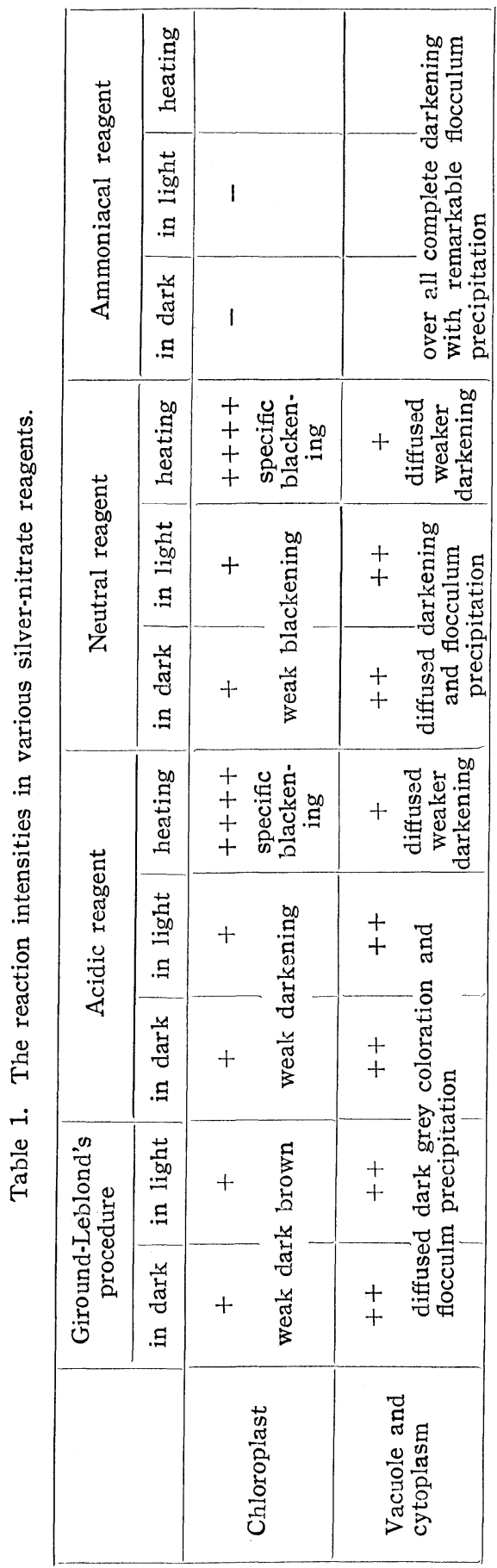

これらの反応は暗処理と明処理とで殆んぞ大差 は熟わられない。

加熱处理：何孔の試菻で加熱によって著しく 反応が強めら狄るが，酸性及び中性試楽で加熱処 理を行った場合に扣いて特に莱緑体が殆んど特暴 的に強く黑化し, 液胞の一様暗化も弱く, 綿毛状 沈殿も微弱で女る（Table 1)。酸性と中性とでは その効果が後者に於て優孔, 又調製に簡便でする から以後の奏験はすべて中性試薬加熱処理法によ った。

又従来報告せられた高等陸生植物では典型的反 応の場合, grana にすず, 還元銀による最も強い 黒化が現か子ることが多かったが，此等沈水楒物 細胞ではすべて，葉緑体の黑化は殆んど一様で女 って, granaに特に著しい知見を得ることはでき なかった。

細胞及び葉緑体の vital activity と還元能:

厄゙ぷん星 一中性試葙加熱処理によって生ず る葉緑体の黒化の強さは一葉でも部分によって強 弱あり，そ玌はヨード試験による葉緑体内同化で んぷん量に略々平行で女った。即ち中肋, 葉脈或 は所謂 Blattfelt 等のでんぷん量の著しい葉緑体 は極わて強く典型的な黒化を示し, 液胞中の綿毛 状沈䟝は少く, 同化でんぷん量の少い縁辺, 基部等 の細胞の葉緑体ではてんぷん量の減少に徉って漸 次顕著な黒色から次第に灰褐色へと反応がうすく なっている。

鹪害 一機械的厄゙ると化学的で女るとを問わ ず㑺害をうけ，死滅した細胞では葉緑体は勿論細 胞質, 液胞にも全く何らの反応をも生じない。生 死両細胞を対比する時その contrast は極鍺 著心要る。

原形質分離 - $0.6 \mathrm{M}$ しょ糖液で処理した細胞 は強く原形質分離を起すがそれ自体は反応の生起 には全く無影響で岁った。しかし原形質分離妈理 が長期問に亘る時は細胞が不健全状態に傾くのは 当然でって，硝酸銀反応子漸時減衰した。

核の存否による禁緑体の変化と硝酸銀反応一 Elodeaでは原形質分離処理により一細胞内に ふ心いて原形体が二塊に分割されることがありそ の上うな場合核を含も分割塊中の葉緑体は次第に 退化して黄化，矮小化し同化厄゙んぷん量屯激減与 るが，核を含まない他广の分割塊中の葉緑体は鮮 緑を保って却って肥大化し著しく同化でんら゚んを 
Table 2. The coloration and intensity of silver-nitrate reaction in the nucleated and enucleated protoplasmic fragments cultured with the $0.6 \mathrm{M}$ sugar solution. The leaf cell of Elodea densa.

\begin{tabular}{|c|c|c|c|c|c|c|c|}
\hline \multicolumn{2}{|c|}{ Cultur duration ${ }_{\text {(days) }}$} & 2 & 3 & 4 & 5 & 6 & 7 \\
\hline \multirow{3}{*}{$\begin{array}{c}\text { Nucleated } \\
\text { part }\end{array}$} & Chloroplast & $\begin{array}{c}++++ \\
\text { black }\end{array}$ & $\begin{array}{c}++++ \\
\text { black with } \\
\text { slight } \\
\text { brown }\end{array}$ & $\begin{array}{l}+++ \\
\text { blackish }\end{array}$ & $\begin{array}{r}+t \\
\text { brown }\end{array}$ & $\begin{array}{c}+ \\
\text { brown }\end{array}$ & $\begin{array}{c}+- \\
\text { yellowish } \\
\text { brown }\end{array}$ \\
\hline & $\begin{array}{l}\text { Morphologica } \\
\text { alteration }\end{array}$ & \multicolumn{6}{|c|}{ shrink, etiolate, and starch decrease. } \\
\hline & $\begin{array}{l}\text { Vacuole and } \\
\text { cytoplasm }\end{array}$ & dark grey & flocculum & precipitation & & faintly & \\
\hline \multirow{3}{*}{ Enucleated } & Chloroplast & $\begin{array}{c}++++ \\
\text { black }\end{array}$ & $\begin{array}{c}++++ \\
\text { black }\end{array}$ & $\begin{array}{c}++++ \\
\text { black }\end{array}$ & $\begin{array}{l}+++ \\
\text { black }\end{array}$ & $\begin{array}{c}++ \\
\text { black }\end{array}$ & $\begin{array}{c}++ \\
\text { black }\end{array}$ \\
\hline & $\begin{array}{l}\text { Morphologica } \\
\text { alteration }\end{array}$ & \multicolumn{6}{|c|}{ enlarge, green, and starch increase. } \\
\hline & $\begin{array}{l}\text { Vacuole and } \\
\text { cytoplasm }\end{array}$ & dark grey & flocculum & precipitation & & faintly & \\
\hline
\end{tabular}

蓄積することは既に報告した4)が，このよろな葉 緑体の変化と硝酸銀反応との関係を検した。その 結果は第 2 表の如くで女って有核部では葉緑体の 変化, 葉緑素量, 同化厄゙んふん量に全く平行的厄 葉緑体の反応は黒加ら次第に褐色，黄裀色と著し く減衰し，液胞内の暗灭出綿毛状沈殿も4～5日 以後は殆んど見られなくなった。これに刘比して 無核部では区応能は極めて強く保たれたが葉緑体 の肥大変化とは平行して増大寸る雪はなく, やは り健全時に比べ狄ば若干減衰の傾向を示した。し かしその程度は前者に初ける程ではなく, 両者の contrast は顕穜で女った。

暗培養と区志一 Elodea, Hydrilla を植えた水 鉢を暗黑中に保った。既に成龍していた葉は暗黑 中に招か扎て子葉緑体は30日後で健全時に比 しそれ程顕著な黄化は起さない。しかし同化でん ぷえは消費し尽され硝酸銀反応の強さむ著しく低 下し僅かに茶褐色を是するに止まる。しかし全く 負となることはなく生死雨細胞を刘比する時生き ている限り反応能が保た扎る寻は明かでする。文 暗保中に新に発した葉は然諭著しく轒化している が細胞が死隇しない限りは硝酸銀反応が全く領と なる㝷はなく, 正負の判定が困難な程微弱になっ てす向生死両細胞を刘比する時は両者の閵に明か
な差を認めることができる。

クロマトグラフィーによる還元性物筫の追求： 往来生体組織に新ける硝酸銀反応を薏起する還元 要因はアスコルビン酸の局在であると多くの研究 は一致した結果を示している。しかし何柾物細胞 に㧤いてはこの反応をアスコルビン酸の組織化学: 的検出法として用いる場合にはより愼重な㮝討を 望を者も专り，二三沈水植物についての上記の検 討結果はこれ迄報告された陸上植物の場合と若干 の相異点む見られる。それでこれらの植物につい てクロマトグラフィーにより硝酸銀還元物質の检 知を試みた結果は第 1図の如くであって，アンモ 二ア性,中性, 酸性の各硝酸銀試楽により徐々にで はあるが何れも顕著なクロマトグラムが現われ， 夫々 $\mathrm{Rf}$ 約 0.08 附近に黒色〜暗灭色のスポット を現わす。Ceratophyllum の場合だけ少しく上 って Rf 約 0.1 位で女る。更に $E$. densa, Hydrilla, Potamogeton では前者に一部重複して Rf 約 $0.13 \sim 0.14$ 附近に長棈四形のもろ一つの大ポ ットをむ現はし，Potamogeton では他の二種類 に比して小さい。又このスポットは同一種に就い ても場会により大小, 強弱を現わすことがあるが， Rf 0.08 の主たるスポットは始んど一定共通であ った。生育条件不良のため還元能の低下している 

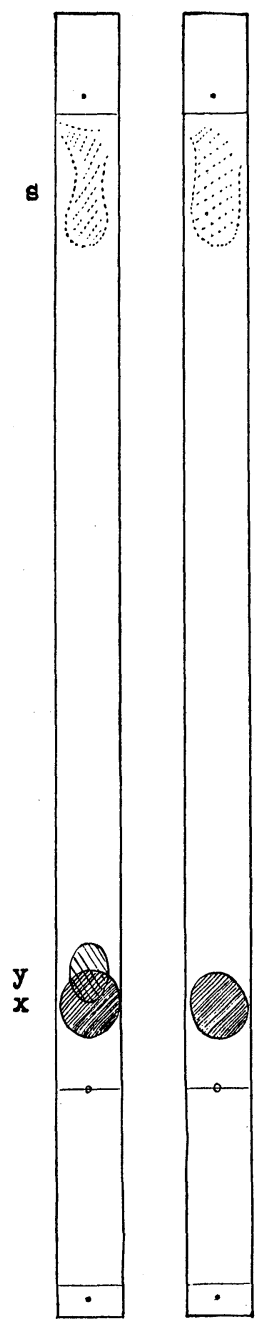

1.

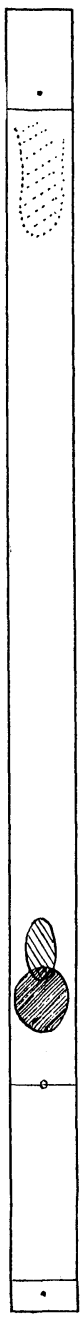

3.

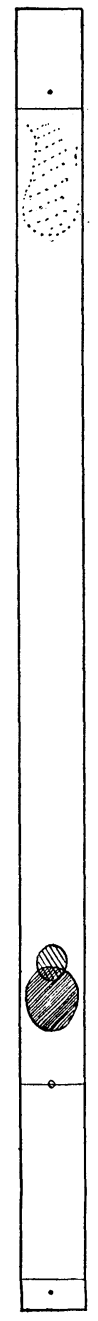

4.

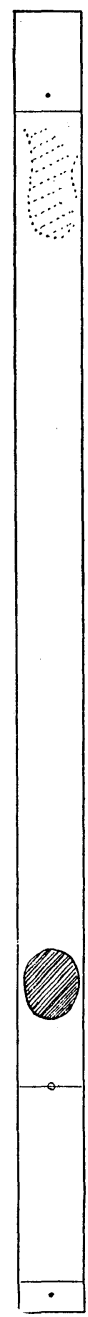

m

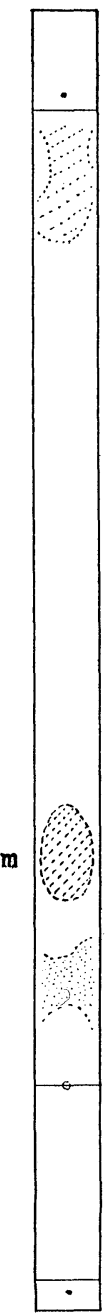

6.

5.

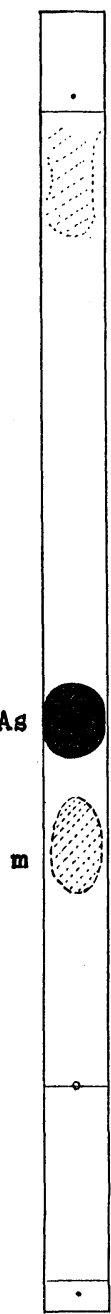

G1
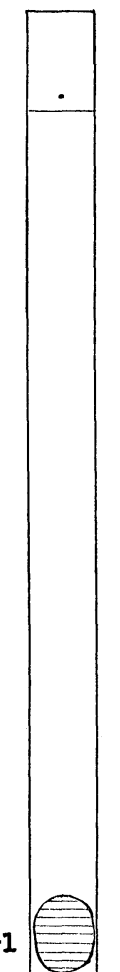

ラフィーの結果とは よく一致し, この大 ポットを生ずる物貿 が細胞内に和ける還 元要因に間違いのな いことを証明してい る。すべての場合に 停止線に達与る細長 い或は少しく纃れた 極めて微弱なスポッ 卜も現われるがこれ は盲検により浴剤に 由来する微量混在物 によるもので女るこ とが分った。これら 被愉液の調製には $5 \%$ 又夕翗酸水溶液 を用いたが， D.W. の多抽出液として 謫製した場合にはこ 狄らのポットは全 く現われないか現わ れても極めて微弱で めって, 安定戍とし てメ夕燐酸の存在を 必要とするもので女 ることを示した。メ 夕燐酸自体も硝酸銀 試楽に反応寸る性質 が女るがメ及燐酸だ けをクロマトグラフ ィーにかけな場合は Rf 0.24 の楕门形暗 灰色の大ポットと Rf 0.11 附近に不明 㙞な暗部を現わすの みであってメ久燐酸 は只還元性物質の安 定剤として働くだけ respectively.

草体及び 30 日間暗培養さ狄て殆んぞ還元能を失 いかけている材料についてのクロマトグすムは Rf 0.13 の大ポットが極为て微弱に見ら扎るだけ で，Rf 0.08 の主たるスポットは殆んど判定に困 難か或は検出せられず，顕鏡的試験とクロマトグ
て Rf 0.8 及び 1.3 のスポットがメタ燐酸によ るものだないことは明かである。この場合メ夕燐 酸自体の大ポットの現れない理由は明らかではな いが何らかの形で還元性物質と結合してそれを安 定化しているのかも知孔ない。 
これらのスポットが何であるか果してアスコル

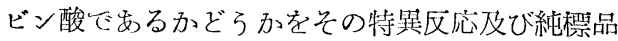
試験と刘照した。アスコルビン酸により特異的に 還元さ狄て青色から舆色になる 2・6-dichlorphenolindophenol 液を䡩色剛とした場合停止線に近 い溶丳由来の大ポットが微紅色を現わした以外青 地に他の変化は現われない。純アスコルビン酸 $5 \mathrm{mg} / \mathrm{cc}$ D.W. 溶液のクロマトグラムは夫々硝酸 銀液で黑褐色，Indophenol 液で青地に白色の Rf 0.4 の明かな大ポットを現わした。同じ純糟品の $5 \%$ メ夕燐酸溶液での試験は Rf 0.375 の所に同 様のより著しいスポットと Rf 0.25 の所にメタ燐 酸の大ポットを現わした。メタ燐酸の存在はアス コルビン酸の Rf 值を低下出しめ自体の Rf 值は 若干上っている。これらの結果と刘照すれば草体 抽出液に和ける硝酸銀罯元のスポットがアスコル ビン酸でないということは確奏で女る。

永井 (1951)5) によ狄ば種によっては 3.4-dioxyphenylalanine (DOPA) が還元にあずかっている 㩽む京り，そ狄は potassium ferricyanide 等に よっても顕出されるといら。しかし報告せられた DOPA のクロマトグラム上の位置は此等草体抽 出液に於ける硝酸銀啐元つ大ポットとは全くかけ 離れた位置にあり，策際 potassium ferricyanide たの顕色試験もここでは全く 反応しなかった。タンニン检 出試薬として用いられる ferric chloride でも全く反 忘を示さずタンニン系物質だ むないと思われる。還元糖検 出のための Partrige-Westall のアンモ二ア性硝酸銀試薬6) により Rf $0.08,0.13$ のスポ ットが暗灰褐色に現われる。 しかし Horrock, Manning (1949) の Benzidin 試薬6) 顕色に於て黄褐色の背景に暗 褐色のスポットの特暴的旺色 像は認められず，却って Rf 0.08 の部分が黄褐色の背景に 少しく空白の末末残される。 Glucose 純糗品のクロマトグ ラフィーの Benzidin 顕色は Rf 0.15 の著しい特異的呈
色像が現われ，これは草体抽出液による Rf 0.13 の硝酸銀還元スポットと位置的に近似してはいる がそれ自身は Benzidin 顕色に全く現われないの であるから此等のスポットが糖でないことす又明 かである。

考察

永井 $(1950)^{7)}$ は陸生高等植物について詳細な 研究をなし典型的な Molisch 反応は酸性試薬に 扔いて最む著しく, アンモニア性では液胞, 細胞 質に一椂黑色綿毛状沈殿を顕著に生ずるが葉緑 体の着色ほ極めて微弱にすぎない。它完なる暗 黒処理では葉緑体の着色は全く起らず，僅かな沈 殿が不替則に生ずるにすぎない事を報告し，同 様の結果は Metzner (1952)8) によっても報告さ れている。それに比べてここで取上げられた沈水 植物細胞では若干反応の梯相に相異点があり，単 に細胞内に生ずる還元銀量だけを見るならばやは りアンモニア性試楽に於て最む著しいが，葉緑体 の特暴的黑化即ち所謂 Molisch 反忘の生起に注 目するならば，勧なる試薬浸漬処理で葉緑体の 者色は幾分か認められるがその程度は弱く, アン モニア性では殆んぞ傎であって，酸性及び中性試 楽による加熱処理に於て最も典型的であり概して

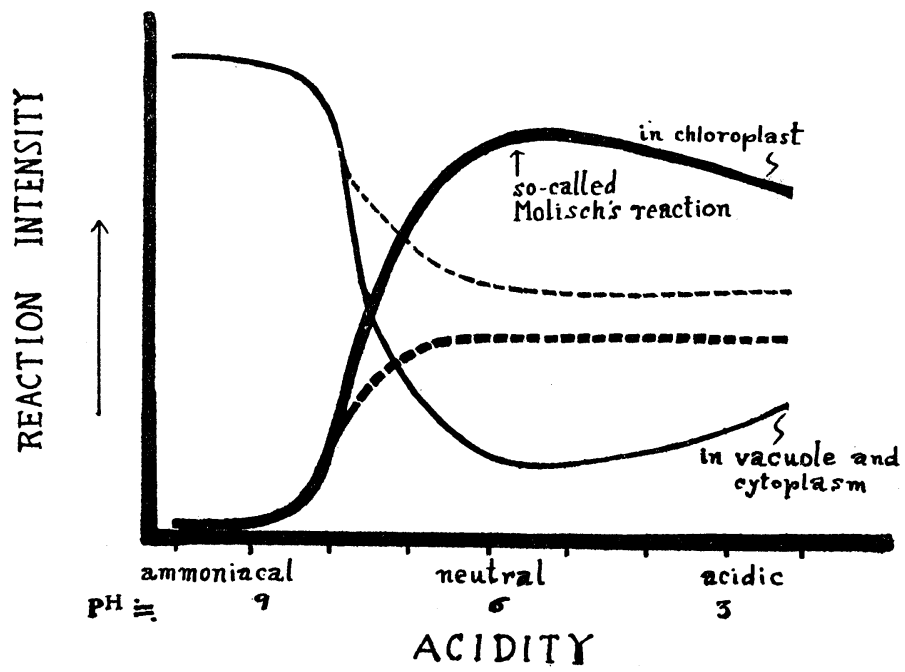

Fig. 2. Experimential diagram showing the relation between reaction intensity in chloroplast or in vacuole and cytoplasm and acidity of silver reagent.

- : Heat treatment.

- .-: Soaking treatment only. 
中性に扣いて優っているようである。(Fig. 2) 永 井・尾形（1952)17) は文海澡では酸性上り中性に 扣いてより好適な特異的結果を弓る事を見ている が此等の場合ももしろそ扎に近い傾问か認められ る。何れの場合にす処理時に約ける明暗条件は反 応に殆んぞ差異を生じて就らず, Gautheret (1938)9), Mirimanoff (1938)10) 等む指適してい るよろな㫕の不可欠性はこの場合必ずしも認めら れない。

所謂 Molisch 反応は葉緑体に就子る還元性物 質の局在によるとの従来の定説に対し, 永井 (19 50)7）はその反応生起の機構について種々の実験 結果から還元性物質はむしろ液胞及び細胞質内に 分散しているのであって，葉緑体の黑化は還元銀 膠質粒子が二次的条件によって吸着されて起る のであると説明し, $\mathrm{pH}$ 出大きく反応生起に影響す るところから荷電関係に上る吸着を考えている。 Caruso (1938)11), Savelli and Caruso (1938, 1939) ${ }^{12}$ '，Danielli (1953)13) 等も還元性物質の葉 緑体への局在を㲛問視し反応生起には他にも要因 がある事を示唆している。Höfler (1939)14）む孔 辺細胞に於て条件により速办に一様分散型, 堞緑 体特黑型が現われる寻を見ている。此等沈水植物 細胞に於ても試薬の酸性度により夫及前記の様に 反灾の様相を異にし、アンモニア性では一様に反 応が強く起るのに酸性に傾くにつ狄葉緑体に顕著 そなるのは此等も同様に酸性度に文配される二次 的吸着により葉緑体反応が生起するものである が，単なる試薬浸漬ではもしろ液胞，細胞質中の 一样暗化, 綿毛状沈粳の方が著しく, 加熱処理 によって始めて強い葉緑体の特異的黑化が見られ るのは, 陸生植物に比べて此等の吸着関係が弱く 加熱処理がそれを飛躍的に拡大するために葉緑体 の特買的黒化をもたらするので, 必ずしも葉緑体 に晾ける還元性物質の局在を意味するものでは なく，還元性物質それ自体は生し子液胞及び細胞 質中に一様に分散して存在しているものと考兄ら れる (Fig. 2)。

Molisch 反応の強さとでんら゚ん量との関係につ いて Höfler (1939)13) は密接に関連する雪を示 し, 永井 (1950 15)，1953 16)）㥀接的関係は認 めら扎ないと言い又黄化した第生之即ち葉緑素の ないものでは反応は生じない事を報告している 一永井・尾形 (1952)17)。ここではでんぷん量
及び葉緑素量と大凡の平行関係が認められたが必 ずしも絕対的なむのでなく，常に平行とは限らな い。これは反応の強さが祀しろ細胞及び葉緑体の vital activityにより密接な連関性をもってい る事を示㖫するもので, でんぷん，葉緑素量即ち 光合成能との平行は間接的なむのであろろ。 Molisch (1918)3)，Geitler (1922)18) 等は既にこ の反応が細胞の生死判別に利朋てきる求を注目 し, 尾形・永井 (1953 19)，1954 20) ) (藻体細胞の 生死，被害判定等に此が有效な奏用的手段である 事を示した。ここでもその事実は明かに認められ， vital activity の低下に平行して反応の強さは減 弱したが細胞が生きている限りはどんなに微弱で あっても生死雨細胞を比較する時は明かに差烡を 認かることができる。原形質分離細胞が正常細胞 と全く同じ反応を示与事は既に永井 (1950)9） む 報告しているがここでも単なる原形質分離々のも のによる細胞の vital activity の低下は少いるの で女る事を示している。

Szent-Györgyi (1928)1) 以来 Giroud-Leblond (1934)21), Bourne (1936)22), Weier (1938)23) 等々の他多くの研究により硝酸銀還元物質はア大 コルビン酸で炙ることが決定せられ，永井・尾形 (1950 7), '51 5), '52 17), ’53 16)) ほ更にクロマトグラ フィーにより詳細広範な研究をなし, 陸生高等植 物のみならず海澡類に就いてもアスコルビン酸が 其通の還元要因である事を明かにした。しかし同 一の手法に良ってなされた此等沈水植物での結果 は全く異った結果を示し，現われた硝酸銀還元大 ポットは被験種に略共通で岁っが予想に反して アスコルビン酸のスポットとは全く異り, 更に DOPA でむなくタンニン系物質てもなく又還元 糖でもなかった。in vitroでのモデル実験の結果 はアスコルビン酸はアンモニア性試菂を最も強く 且つ敏感に還元することを示し，永井 (1951)5) もクロマトグラフィーでアンモニア性試槳がイン ドフェノール試楽についで強くアスコルビン酸を 検出し得る雪を報告し，又アスコルビン酸以外に もフラボノイド, タンニン, 還元糖等種々のスポ ットが現われる等も岁ったが，こ和らはすべてア ンモニア性試楽でのみ検出され，酸性試槳では反 応しなかったという。そ扎に刘しこの場合はアン モニア性, 中性, 酸性のすべての試薬に反応し陸 生高等植物又び海澡類等に新けるものとは異った 
別の物質であると思われる。 Rf 0.08 及び 0.13 の此等の物質は何孔す分解乃至は酸化を受け易い 不安定な物質で出って，抽出に際しては安定剤と してメタ燃酸の存在を必要とする事はアスコルビ ン酸に類似しているが還元力は比較的に弱く鈍 い。 Rf 0.13 のスポットは E. canadensis, Ceratophyllum では現わ狄ず，又場合によりかなり消 長があって不安定で還元力も弱く，此の意義は往 属的なむので女ると思わ狄る。此等二つのスポッ トが物質的に何で女るかは佮決定できなかった が，此等沈水植物ほ陸生植物に比し若干の点で相 異が認められるが大凡類似の著しい還元反応を示 すにも拘らず還元物質の分析は全く違った物質の 存在を示した柔は注目に值しよう。

Giroud-Leblond 法はアスコルビン酸の細胞化 学的検出法としては必ずしもその特異性及び骺感 度が十分でない事は既に Mirimanoff (1938)24), 新家・重永 (1947) 25), 飯岛・平岡 (1950)26)，及 び Danielli (1953)13) 等によって注意され，又種 によっては苳酸の存在が著しく反応に干渉する事 が永井・尾形 (1952)17) によって明かにされた。 沈水植物に䏡いては上記の実験結果がアスコルビ ン酸以外の物質によった事を明かにし，又試楽の $\mathrm{pH}$, 加熱等の二次的条件による反応生成物の著し い易動性はこの処理法が細胞化学的検出法として すべての場合に絶対的にアスコルビン酸の存在及 びその局在性を示するのとは言い切れず，反応結 果つ判定には向より以上に憤重な考慮が必要とさ 犯るでらう。

傷書を受け，死隇した細胞での還元反応の消失 は極めて鋭敏で如っ生死両細胞の刘照は全く顕 著であるが，Weier (1938)23) によればこれは還 元性物質が酸化されて還元力を失ろからで女っ て，酸化を防止する条件下では死細胞でも反応の
生起を認わ得たと言う。この場合安定珮としてメ 夕铭酸が存在すればこの還元性物質は磨砕抽出に よってもクロマトグラフィーに㧤いて充分強い還 元力が保持されていたが，メ夕燐酸液中に招いて 切断された細胞でも顕微鏡下では完全に反応能を 失い，又単にメ及燐酸液中に浸漬せられただけで むとれによって書をうけ原形質は不規則に收縮 し,硝酸銀反応は負となった細胞外に磨砕抽出せ られる場合にすらメタ燐酸は充分有效な安定剤で 女るのだから，たとえ傷害死滅細胞内に拈いても この場合還元性物質は安定化されている筈で，葉 緑体の特異的黒化はとあかくとしても少くとも一 次的な硝酸銀還元は起ってよいと思われるのに顕 微鏡下に就いて全く何らの反応も認められないの は奇妙である。in vivoに拝いては“生きている” そいう何らかの微妙な条件が必要なのであるか, 或は又還元性物質自体はメ夕耀酸により安定化さ れてはいてす死滅細胞には反応を阻止する条件が 出現するのであろろかとも考元られる。E. canadensis のメ夕燐酸磨砕遠心上澄液に中性硝酸銀液 を滴下したところ著しく白濁し, 带淡黄褐色の沈 虎を生じ，先にアスコルビン酸での in vitro の モデル試験に新いて見られたような還元銀の白色 沈㱆は認めら狄なかった。この状海は永井・尾 形 (1952) ${ }^{17)}$ が反応干涉物筫の研究で報告してい る状況と類似している。クロマトグラフィーで展 開されれば各物質が単㒕され，安定化された還元 性物質は他に好げられることなく硝酸銀試薬によ り暗灰色のスポットを生ずるのかも知れない。し かし此等の関係を説明するためには份将来の検討 にまたねばならない。

終りに有益な御助言を下された本学教育学部 相馬悌介漖授, 宋京教育大学植田利喜造助教授に 謝意を表する。

\section{Summary}

Several studies on the silver-nitrate reduction in the cells of five species of the submerged plants were carried out.

1. The reduction occurred as in the land plants, but the specific blackening of chloroplast (so-called "Molisch's reaction") was most typical when the material was heated with neutral silver reagent.

2. The light and dark conditions in procedure had no influence on the occurrence of reduction. 
3. The speeific blackening of chloroplast does not always indicate the localization of the reducing agent in it. It is due to the secondary deposition of reduced silver on chloroplast, and the agent is rather contained diffusely through the vacuole and cytoplasm.

4. The parallelism between the reaction intensity of chloroplast and the starch and chlorophyll contents was not always absolute, but it was connected rather more closely with the vital activity of cell and chloroplast.

5. The trials of detection of reducing substances by means of the chromatography showed the silver reducing spots in the position of $\mathrm{Rf} 0.08$ in all cases and also of 0.13 in a few cases. These spots were not ascorbic acid, DOPA, reducing sugar, tannin nor flavonoid etc. For the extraction of these substances the presence of metaphosphoric acid was necessarily required as a stabilizer. The identification of these substances is as yet remained unsettled.

6. It must be considered, from these facts, that the Giroud-Leblond's procedure or silver-nitrate reagent are not always sufficiently specific in all cases for ascorbic acid in the cytochemical use.

\section{Literatures}

1) Szent-Györgyi, A., Biochem. J. Z2: 1387 (1928). 2) Giroud, A. and Leblond, C.P., Biol. Ztbl. 57 : 658 (1937). 3) Molisch, H., Sitz. berich. d. kais. Akad. wiss. i. Wien. Abt. 1. 127 (1918). 4) Yoshida, Y., J. Fac. Sci. Niigata Univ. Ser, II. 2: 73 (1956). 5) Nagai, S., J. Inst. Polytech. Osaka City Univ. 2 : Ser. D. 1 (1951). 6) Kuwada, S., Chromatography, Tokyo(1951). 7) Nagai, S., J. Inst. Polytech. Osaka City Univ. 1: Srr. D. 33 (1950). 9) Metzner, H., Protoplasma 41 : 129 (1952). 9) Gautheret, R., C.r. Akad. Sci. Paris. 198: 1252 (1938). 10) Mirimanoff, A., Rev. gen. Bot. $50: 333$ (1938). 11) Caruso, C., Protoplasma 30: 341, 481, 31: 98, 489 (1938). 12) Savelli, R. and Caruso C., ibid. $32: 397$ (1938), $32: 517$ (1939). 13) Danielli, J.F., Cytochemistry, New York (1953). 14) Höfler, R., Protoplasma $33: 258$ (1939). 15) Nagai, S., Bot. Mag. Tokyo 63: 250 (1950). 16) - J. Inst. Polytech. Osaka City Univ. 4: Ser. D. 27 (1953). 17) Nagai, S. and Ogata, E., ibid. 3: Ser. D. 46 (1952). 18) Geitler, L., Öster. Bot. Zts. 71 : 116 (1922). 19) Ogata, E. and Nagai, S., Bull. Jap. Soc. Sci. Fisher. 19: 1750 (1953). 20) — Physiology and Ecology $6: 10$ (1954). 21) Giroud, A. and Leblond, C.P., C. r. Soc. Biol. 115: 705, 841 (1934). 22) Bourne, G., Anat. Rec. 66: 369 (1936). 23) Weier, E., Amer. J. Bot. 25: 501 (1938). 24) Mirimanoff, A., Rev. Cytol. Cytophysiol. Veget. $3: 119$ (1938). 25) Shinke, N. and Shigenaga, M., Rep. 74 Div. Sci. Counsil (1947). 26) Iijima, M. and Hiraoka, T., Bot. Mag. Tokyo 63: 278 (1950). 